\title{
IMPROVEMENT OF ADMINISTRATIVE-TERRITORIAL SYSTEM FROM THE STANDPOINT OF HUMAN GEOGRAPHY (THE CASE OF KORETS DISTRICT, RIVNE REGION)
}

\author{
'Iryna OSIPCHUK, ${ }^{2}$ Pavlo CHERNYAK, ${ }^{3}$ Vitaliy BRYZH \\ ${ }_{1,2,3}$ International University of Economics and Humanities named after academician Stepan Demianchuk, \\ Rivne, Ukraine \\ 'osipchukira@ukr.net
}

\begin{abstract}
The article describes the international experience of the administrative-territorial reform, particularly in the postSoviet countries such as Estonia, Latvia, Georgia and the post-communist Czech Republic. The paper reflects the history, the main approaches and principles of administrative-territorial reforms have been applied in these countries, as well as the challenges that countries have faced in the process of the reform. The authors made an attempt to analyze administrative-territorial division of the listed countries at the present stage and in Soviet times, considered transition are described.

We also considered modern structure of the administrative-territorial division of Ukraine at all levels and performed the analysis of perspective plan of changing the administrative-territorial division in Korets District of Rivne Region by combining the twenty five rural and one urban council in the two enlarged territorial communities with the elimination of the district level, considering the modern structure of the area in the view of main geographic parameters. The main parameters of this analysis are community population, land area and own financial resources. Also, we built map-chart of contemporary and future division of the district depicting the basic elements of the administrative-territorial division. According to the figures it was concluded that enlarged communities, proposed by the perspective plan, are comparable and suggested division is rational.
\end{abstract}

Key words: administrative-territorial reform, municipality, community, Korets district, Rivne Region.

UDC: 911.3

\section{СУСПІЛЬНО-ГЕОГРАФІЧНІ АСПЕКТИ УДОСКОНАЛЕННЯ АДМІНІСТРАТИВНО- ТЕРИТОРІАЛЬНОГО УСТРОЮ НА ПРИКЛАДІ КОРЕЦЬКОГО РАЙОНУ РІВНЕНСЬКОӦ ОБЛАСТІ}

\author{
'Ірина ОСІПЧУК, ²Павло ЧЕРНЯК, ${ }^{3}$ Віталій БРИЖ \\ 1,2,3Міжнародний економіко-гуманітарного університет імені академіка Степана Дем'янчука, Рівне, Україна \\ 'osipchukira@ukr.net
}

\begin{abstract}
Анотація: У статті розглянуто зарубіжний досвід проведення адміністративно-територіальних реформ, зокрема у таких пострадянських країнах як Естонія, Латвія, Грузія та посткомуністична Чехія. Висвітлено історію, основні підходи та принципи проведення адміністративно-територіальних реформ, які були застосовані у цих країнах, а також проблеми, з якими країнам довелося зіткнутися у процесі такого реформування. Описано структуру адміністративно-територіального поділу цих країн на сучасному етапі та за радянських часів, розглянуто перехідні етапи.

Також розглянуто сучасну структуру адміністративно-територіального поділу України на всіх рівнях. Здійснено аналіз перспективного плану зміни адміністративно-територіального поділу Корецького району Рівненської області шляхом об'єднання двадцяти п'яти сільських та однієї міської рад у дві укрупнені територіальні громади із ліквідацією районного рівня та його сучасну структуру за основними суспільно-географічними параметрами. Основними параметрами такого аналізу $\epsilon$ кількість населення, територія та власні фінансові ресурси, якими володіє громада. Побудовано картосхему сучасного та перспективного поділу райони на первинні елементи адміністративно-територіального поділу. Зроблено висновок, що за даними показниками запропоновані у перспективному плані укрупнені громади $\epsilon$ пропорційно співставними і такий поділ $\epsilon$ доцільним.

Ключові слова: адміністративно-територіальна реформа, муніципалітет, громада, Корецький район, Рівненська область.
\end{abstract}

DOI: http://dx.doi.org/10.17721/2413-7154/2016.75.12-20

УдК: 911.3

Вступ. Постановка проблеми. Реформування та вдосконалення адміністративно-територіального устрою на сучасному етапі суспільно-політичних змін, що насамперед, пов'язані із процесами децентралізації влади, є чи не найважливішими серед низки суспільно-географічних проблематик.

(C) I. Осіпчук, П. Черняк, В. Бриж
Система діючого адміністративно-територіального устрою України успадкована від радянської системи, для якої пріоритетними були питання жорсткого централізованого управління та ефективності планово-розподільчої економіки. На сьогодні акценти мають бути зміщені у бік розвитку базових елементів адміністративно-територіального устрою 3 урахуванням наявності у кожної конкретної громади ресурсів для ефективного господарювання. 
Аналіз останніх досліджень і публікацій. Серед науковців зазначену проблематику частково досліджували Р. Безсмертний, А. Доценко, В. Кравченко, I. Кресіна, А. Коваленко, В. Олуйко, С. Телешун та інші. За участю науковців напрацьовано низку концепцій адміністративно-територіальної реформи та вдосконалення системи територіальної організації влади в Україні, зокрема: проект концепції реформи місцевого самоврядування, Концепція реформи адміністративно-територіального устрою України, яка визначає основні засади організації адміністративно-територіального устрою та формування адміністративно-територіальних утворень, їхню типологію; організацію публічної влади на відповідних рівнях; законодавче забезпечення та етапи проведення адміністративно-територіальної реформи. Водночас зазначених концепцій досі не реалізовано, що свідчить про недостатне наукове обгрунтування їх та не дає можливості усунути недоліки в системі адміністративно-територіального устрою України.

Формулювання цілей статті. Постановка завдання. Метою статті $€$ здійснити суспільногеографічний аналіз діючої та перспективної схем адміністративно-територіального поділу Корецького району Рівненської області; розглянути досвід проведення адміністративно-територіальних реформ у інших пострадянських країнах.

Виклад основного матеріалу. Для того щоб зрозуміти, які можливі ускладнення чекають Україну у процесі адміністративно-територіального реформування, розглянемо у загальних рисах європейський досвід.

3 1960-х років у європейських країнах простежується тенденція до укрупнення територіальних одиниць. Майже кожна країна північно-західної частини Європи зменшувала кількість територіальних одиниць найнижчого рівня - за останні 50 років їх кількість скоротилася у 4 рази. У деяких країнах це було викликано необхідністю підвищення ефективності надання комунальних послуг та розподілу державних інвестицій, у інших це стало результатом проведення загальнодержавних реформ, а деякі країни відмовилися від такого реформування, розширивши співпрацю між місцевими громадами. Більшість досліджень, що зосереджені на питаннях розміру та ефективності місцевих органів влади розглядають громаду як базовий елемент АТУ, оскільки обсяги бюджетних витрат тісно пов'язані з рівнем місцевих доходів, а, відповідно, і кількістю платників податків. Площа території муніципалітету, густота населення та поселенської мережі також впливає на ефективність місцевих органів влади, але слабше, як кількісні та якісні показники населення.

В залежності від традицій, географічних умов, політичних інтересів та інших важливих чинників середня людність місцевої громади у 27 країнах ЄС коливається від 1,5 тис осіб (Кіпр) до понад 150 тис (Великобританія), а середня величина -

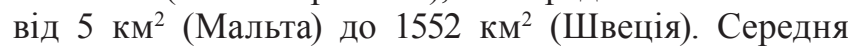
людність місцевих громад становить 5530 осіб. Це дещо перевищує показник оптимальної людності для забезпечення ефективності та зменшення затрат, що складає 5 тис осіб (запропонований на основі обчислень всіх 91316 муніципалітетів 27 країн (С). Однорівнева система адміністративнотериторіального устою була застосована у країнах, де на місцеві громади покладаються значні обсяги затрат на комунальні послуги (невеликі країни та Фінляндія). Більшість країн визнала необхідність вищих рівнів органів влади, що забезпечують надання послуг, які є недоступними на найнижчому piвні. Таким чином, в 11 країнах $\epsilon$ дворівнева система місцевих органів влади, в той час як в більшості великих країн сформувалася федеральна або квазіфедеральна структура. За попередні 20 років спільна тенденція в країнах-членах ЄС щодо вищих рівнів управління, спиралася на посилення або поновлення регіонального рівня 3 одночасним розширенням повноважень регіональних органів управлінь. Зрозуміло, що складно знайти загальні підходи щодо АТУ країн $Є C$, оскільки методика, застосована для однієї країни, має бути всебічно переглянута у випадку іншої країни. Навіть в межах однієї країни чинники, що сприяють чи перешкоджають консолідації, можуть сильно відрізнятися і мають свої особливості.

Вирішення територіальних проблем завжди $\epsilon$ дуже важливими для країни. Географічні, еконо-мічні, політичні фактори, такі як розмір і конфігурація території країни, етнічна структура, спеціалізація (сільськогосподарська, індустріальна, сфери послуг) та структура системи державного управління завжди спричиняють вплив на адміністративно-територіальний поділ. Проте, дослідження наслідків адміністративнотериторіальної реформи в певній країні може продемонструвати можливі проблеми та типові помилки, яких можна оминути [1, c.11 - 13].

Для порівняння розглянемо Чехію, Естонію, Грузію та Латвію.

Чехія. Територія Чехії має сильно розчленований рельєф, що значною мірою впливає на іiï територіальний поділ. Високий розвиток промисловості та сфери послуг у післявоєнний період сприяли концентрації населення у містах рівень урбанізації тут становить $71 \%$. Відповідно, система територіального управління базується на містах, яких налічується 593. Проте, через високий рівень роздробленості адміністративнотериторіальних одиниць, майже $9 \%$ АТО найнижчого рівня (муніципалітетів) приурочені до міст та містечок. Чехія має одну із найбільш роздроблених систем АТУ у Свропі. Із середнім розміром міських населених пунктів близько 1600 жителів і площею $13 \mathrm{\kappa м}^{2}$ та $80 \%$ місцевих громад із населенням до 1 тис осіб, вона має досить сильну схожість із французькою системою. Під час комуністичного режиму відбувся ряд послідовних вимушених реформ щодо зменшення кількості муніципалітетів в три рази, приблизно від 11500 в 1950 році до близько 4120.

За часів незалежності місцеві цінності демократії були розглянуті як право будь-якої громади 
мати свій орган влади, і кількість громад знову зросла (до 6250). Оскільки не було чітких критеріїв для поділу, таких як мінімальна кількість населення, збільшилась кількість громад із населенням 50-500 жителів, що складало 60 \% їх загальної кількості. Це призвело до обмеження доходів місцевих бюджетів i, як результат, більшу залежність від державних дотацій. Оскільки можливість об'єднання була виключена через загальне сприйняття як згадки про тоталітарний режим, спричинявся тиск на місцеву та центральну владу для пошуку альтернативного рішення.

Спроби зупинити чи, принаймні, стабілізувати процес подальшого дроблення були невдалими. Громади висували аргументи щодо місцевої автономії і посилалися на приклади примусового об'єднання громад при комуністичному режимі. Подальший процес роздроблення вдалося зупинити лише у 2000 році із прийняттям мінімальної чисельності новоствореної громади, що складала 1000 жителів. Також для зменшення наслідків високої роздробленості було запроваджено ряд заходів:

1. За законом добровільне об'єднання громад заохочувалось, але це не призвело до значної кількості об'єднань. Централізоване втілення процесу об'єднання практично не можливе, оскільки Чеська Конституція забезпечує гарантії місцевого самоврядування. Було прийнято альтернативне рішення про збільшення податкових надходжень на одну особу в залежності від розміру громади. Проте, це не сприяло процесу злиття громад, скоріше через те, що невеликі громади мають невеликі бази для оподаткування, а об'єднання не призвело б до значних збільшень податкових надходжень;

2. Підтримувалась кооперація між громадами щодо надання послуг населенню;

3. В централізовано розробленій програмі громади із обмеженими можливостями щодо забезпечення певних послуг делегували ці повноваження більшим міським громадам.

Іншим важливим аспектом територіальної реформи на початку 90-х було скасування другого рівня місцевого управління. Регіональний рівень, що сприймався як інструмент колишньої комуністичної влади для партійного контролю, повинен був зникнути. Натомість з'явилися «окружні офіси», що підпорядковувалися центральній владі і взяли на себе обов'язки регіональних управлінь.

Чеська Конституція передбачає дворівневу систему адміністративного управління. Відповідно у 1997 році було затверджено два напрямки тиску щодо створення вищого рівня регіонального управління. Перший, функціональний, вказував на необхідність існування регіональних органів влади для підтримки слабких громад, делегування деяких повноважень від центральних органів влади. Інша форма впливу була зовнішньою і прийшла з СС i була спрямована на відновлення регіональних рівнів для реалізації їх регіональної політики. Дана поправка вступила в силу у 2000 році, коли були проведені перші вибори до регіональних рад.
Протягом останніх десятиліть дана система залишається діючою. 3 точки зору повноважень, місцеві громади мають унікальний набір власних обов'язків, що фінансуються їх власними доходами - початкові школи, дитячі садки, газота електропостачання, збір та утилізація відходів, громадський транспорт та місцеві автошляхи, соціальне житло, театри, бібліотеки та музеї, зони відпочинку, водопостачання, вуличне освітлення, пожежні частини, кладовища тощо. Делеговані державою повноваження залежали від певних критеріїв, таких як кількість населення, централізованість і за цими критеріями всі громади поділяються на три типи:

Тип I - охоплює майже 93 \% громад, повноваження яких пов'язані з власною адміністративною територією та інколи основні делеговані повноваження (напр. управління при надзвичайних ситуаціях);

Тип II - 388 громад із власним місцевим офісом;

Тип III - 205 громад із розширеними повноваженнями.

Другий та третій тип варто розглядати як центри обслуговування для прилеглих територій, а не як одиниці вищого рівня [1, с. 18-23].

Естонія. Дія фізико-географічних умов на територіальний поділ країни є подвійною. В Естонії добре розвинене сільське господарство, в той час як за СРСР був розвинутий промисловий сектор (енергетика і хімія). Радянська система планувала створити і підтримати малі адміністративні одиниці. Відносно високий рівень урбанізації ( $70 \%$ спричинив формування великої кількості міських громад (47 \% міст). Майже $15 \%$ естонських адміністративних одиниць першого рівня муніципалітетів - організовані навколо міст.

Естонія була першою країною східного блоку, яка прийняла закон про місцеве управління в 1989 році. В Естонії за попередні 30 років визначилися сільські муніципалітети і міста як головні одиниці місцевої влади. 31 січня 2010 року адміністративний округ Естонії включає 15 округів та 277 адміністративних одиниць 3 місцевими органами влади, включаючи 33 міста, 193 сільських муніципалітетів і 14 міст без муніципалітетів.

Середнє число населення Естонських муніципалітетів близько 5904 осіб. Є також велика кількість муніципалітетів (80 \%) у яких проживає менше ніж 5 тис. осіб, близько $37 \%$ муніципалітетів мають менше 1500 тис жителів. Густота населення Естонії низька. Оскільки в Естонії сільські муніципалітети і міста були доволі таки слабкими, щоб приймати певні обов'язки, панувала дворівнева система, яка була прийнята в 19891993 роках, тоді всі колишні сільські і міські ради отримали статус місцевої одиниці самоуправління. Щоб отримати такий статус, вони повинні були підготувати соціально-економічний план розвитку i винести його на розгляд парламентської комісії 3 адміністративної реформи.

Відносний успіх місцевого самоврядування в Естонії може пояснюватися раннім прийняттям 
конституційних положень про самоуправління. Зокрема, 14 глав щодо «Місцевих органів влади» гарантують незалежний місцевий бюджет і право накладати податки. Згідно із законом про місцеве самоврядування, у місцевих органів влади є певні організаційні функції в сільських муніципалітетах чи містах щодо соціальної допомоги і послуг, роботи для молоді, послуг житла, води і каналізації, надання комунальних послуг, послуг громадського транспорту, обслуговування сільських доріг муніципалітету і міських вулиць. Місцеві органи влади також відповідальні за організацію і обслуговування перелічених нижче установ за умови, що вони знаходяться у власності муніципалітету: це середні і професійно-технічні школи, бібліотеки, музеї, спортивні комплекси, будинки соціального обслуговування, заклади охорони здоров'я тощо.

Фінансова автономія місцевих органів влади в Естонії більш широка, ніж в інших країнах СС. Закон про місцеві податки дозволяє місцевим радам накладати податки 3 продажу; рекламний податок; податок $з$ автотранспорту; податок на тварин (однак деякі 3 них ніколи не використовувалися жодним органом влади). Сільський муніципалітет і міське управління являються податковим органами в межах їх адміністративної території, які формують перелік місцевих податків. Місцеві органи влади незалежні у своєму формуванні бюджету. В Естонії місцеві органи влади отримують дотації із фонду державної підтримки, що створений в межах державного бюджету 3 метою згладити відмінності у рівні доходів [1, с.23-29].

Латвія. Для Латвії характерними є переважно рівнинний рельєф, який не створює значних ускладнень для адміністративно-територіального поділу, та відносно несприятливі умови для ведення сільського господарства. За радянських часів тут розвивалась обробна промисловість, що сприяло прискореній урбанізації. Радянська планово-розподільча система вимагала утворення та підтримки відносно маленьких адміністративних одиниць для полегшення управління та наближення влади до населення. Притаманний високий рівень урбанізації (70 \%) обумовив базування місцевого управління на міських громадах (77 міст). Близько $65 \%$ адміністративних одиниць найнижчого рівня тяжіють до міст.

Відразу ж після здобуття незалежності Латвія мала дворівневу систему місцевого управління. Перший рівень громад представлений містами державного значення, містечка, села та різні об'єднання останніх двох. Другий рівень був раніше відомий як райони, успадковані від радянської влади. У Конституції Латвії 1992 року не прописані принципові позиції місцевого управління. Після декількох несистемних спроб територіального об'єднання громад у 1997 році вийшов закон про самоуправління громад, що запроваджував зобов'язання місцевих громад зі слабким розвитком інфраструктури співпрацювати 3 іншими місцевими органами влади для виконання власних зобов'язань. Хоча багато громад підпадали під цю категорію, процес не набув значного поширення. У 1998 році Латвійський Парламент прийняв Закон про адміністративно-територіальну реформу. Він стосувався мети, термінів, процедури, фінансового стимулу та інституційної координації реформи. У загальних рисах, запланований процес передбачав фінансові стимули для громад, що добровільно об'єднаються, у різних об'ємах за різні терміни.

Друга стадія передбачала адміністративне (вимушене) об'єднання у 2004 році та проведення місцевих виборів у 2005 році. Проте до 2005 року було здійснено лише 26 об'єднань, оскільки реформа зіткнулась із опором місцевих еліт та діючої місцевої влади. До закону було внесено ряд поправок, головною з яких був перехід до однорівневої системи місцевого управління на базі районів. Відміну окружного рівня вважали суттєвою перемогою, оскільки райони були політично, економічно і соціально досить слабкими, щоб справляти вплив на регіональний розвиток. Як i планувалось, об'єднання громад здійснювалось лише після всебічного дослідження ставлення населення, соціально-економічних наслідків такого об'єднання

Зміни у адміністративно-територіальному устрою Латвії до та після 2009 року

Таблиця 1

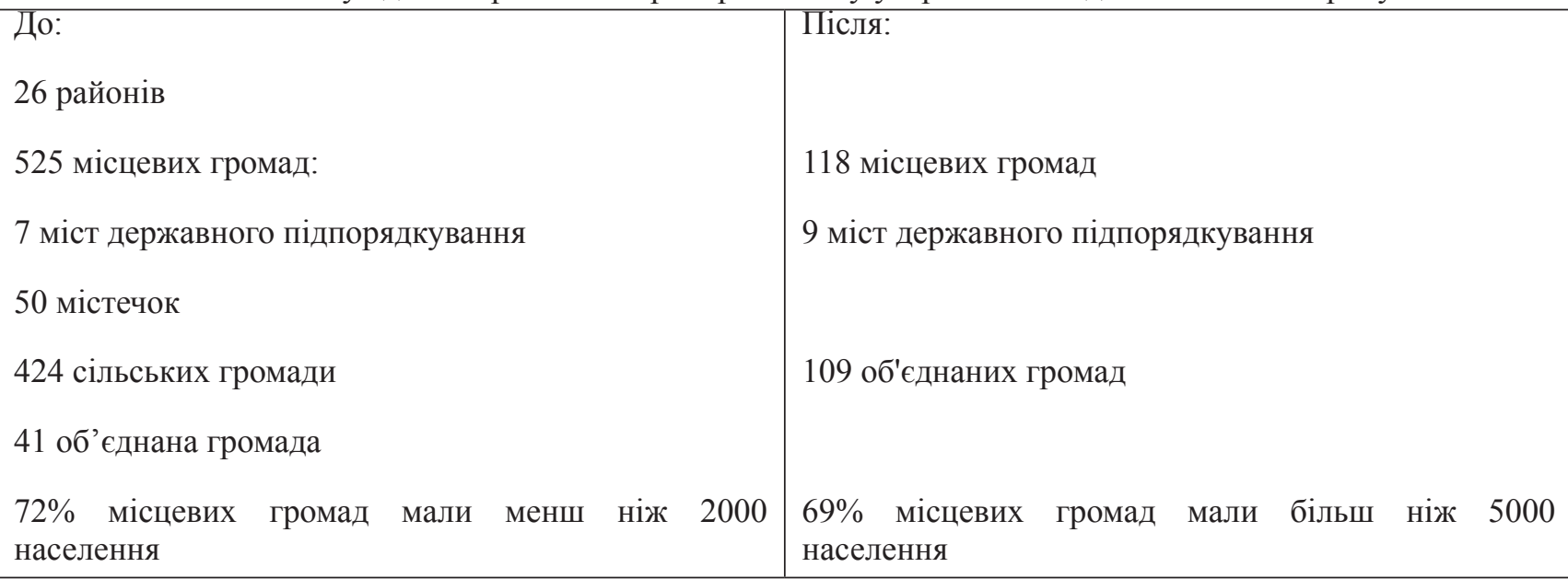


i формулювання завдань та умов, які необхідно виконувати у випадку кожного об'єднання для того щоб воно дало позитивні результати.

Відповідно до закону, для того щоб здійснити об'єднання необхідно було взяти до уваги наступні критерії:

- можливість забезпечення довготривалого та збалансованого розвитку території;

- наявність інфраструктури для виконання завдань місцевого управління;

- розмір території;

- кількість постійного населення;

- густота населення;

- доступність послуг, що надають місцеві органи влади;

- економічна, географічна та історична однорідність місцевих громад, що об'єднувалися, враховуючи інтереси сусідніх громад.

Щодо розмірів громад, кінцевий результат продемонстрував, що середній розмір громади, за виключенням Риги, складав 19000 осіб, що наближено до польського, бельгійського та фінського показника. 37 громад мають населення близько 5000 і тут сконцентровано близько 6 \% населення Латвії.

Важливими уроками латвійської адміністративно-територіальної реформи можна вважати такі:

- добровільне об'єднання громад доречне, коли є вдосталь часу для вибору оптимального варіанту об'єднання, проте, якби цей процес не носив обов'язковий характер, він би міг затягнутися;

- фінансового заохочення не достатньо для заохочення добровільного об'єднання громад;

- механізм має бути чітко окреслений у загальних рисах у інструкціях i має бути життєздатним, а нова влада не відкидає зобов'язань попередньої;

- можливі виключення мають бути чітко визначені [1, с.35 - 41].

Грузія. Висока розчленованість рельєфу Грузії створює значні труднощі для адміністративнотериторіального поділу. Крім того, даний процес сильно залежить від етнічної структури та політичних вподобань населення. 3 огляду на природні особливості території, історично сформована територіальна структура мало змінювалась як у дорадянський та радянський, так i у пострадянський період. За радянського періоду у Грузії розвивалась сфера послуг та сільське господарство, та 3 огляду на середній показник урбанізації (53\%) та розчленованість рельєфу державна система управління менш приурочена до міст (усього у Грузії налічується 55 міст та 48 смт). Всі адміністративні одиниці першого порядку, на перший погляд, знаходяться під управлінням міста чи селища міського типу, проте через певні особливості останньої адміністративно-територіальної реформи, більшість із них мають значну частку сільського населення і по суті є сільськими громадами. Таким чином, частка міського населення у сільських громадах коливається від 0-3 \% до 63 \%.
Протягом 90-х років у Грузії зберігалась сильно централізована багаторівнева система місцевого управління. Через внутрішньодержавні конфлікти централізація розглядалась як єдиний інструмент для недопущення розпаду держави. Хоча перший закон про місцеве самоврядування був прийнятий на початку 1991, більш-менш стабільна адміністративно-територіальна система з'явилась у 1994 році і включала 9 регіонів з централізовано призначеними губернаторами, 65 районів, 48 міст та містечок та близько тисячі сільських поселень.

На відміну від інших країн, у Конституції 1995 року Грузія не затверджувала АТУ країни: у ст.2 вказано, що такий устрій буде затверджено лише після повного встановлення правових відносин по всій території країни. Закон про місцеве самоврядування 1997 року визначав дворівневу систему місцевого управління. До першого рівня належали 1033 елементи - села, об’єднані села, містечка (смт) та міста, а до другого - 65 районів. На передодні «Трояндової революції» Грузія мала 4-рівневу систему управління, яка складалася 3 автономних республік, які у певних випадках мали власну внутрішню територіальну організацію. Перша великомасштабна територіальна реформа розпочалась у 2005 році, коли Парламент прийняв новий закон про місцеве самоврядування. На найнижчому рівні тут дозволялося об'єднати 1033 громади у 64 укрупнених місцевих органи влади (злиття сільських та міських громад), що базувалися на основі районів. Також 5 найбільшим містам, включаючи Тбілісі, було надано спеціальний статус. Здавалося, що рішення про створення органів місцевої влади на основі районів було прийнято із розрахунку, що реформа пройде швидко і не викличе значних протиріч. Крім того, у цьому випадку не було необхідності шукати складні критерії об'єднання громад.

На вищому рівні 12 регіонів у період після реформи 2005-го не могли розглядатися як проміжні рівні місцевого управління, оскільки вони не мали виборних рад і регіональні губернатори призначалися Президентом. Два автономних регіони можна було розглядати як додатковий рівень місцевого управління, який поширюється виключно на їхню територію.

У Грузії є лише дві громади, що налічують менше ніж 5000 жителів. Якщо не враховувати показники Тбілісі та інших міст спеціального статусу, середній розмір громади складає близько 44000 жителів. Такі показники характерні для Данії, Литви та Ірландії, які входять до п’ятірки країн $\mathrm{CC}$ iз найвищими показниками людності громад. Проте для місцевих органів влади великих громад географічні чинники в Грузії (високогірний ландшафт та погана якість автошляхів) створюють проблеми для якісного та ефективного обслуговування населення. Досягнення суттєвих змін у кількості та розмірах місцевих громад не принесло очікуваної децентралізації влади та фінансів. Викликана внутрішніми конфліктами та війною 2008 року централізація 90-х років залишалася актуальною. Відомо, що європейська 
система місцевого самоврядування була ратифікована Грузинським Парламентом наприкінці 2004 року i лише впливала на функціональний розподіл влади між місцевими та центральними органами. У 2005 році під час реформи було виділено три групи місцевих громад: 3 виключними, делегованими та добровільними повноваженнями. Проте це не принесло суттєвих змін у функціональні обов’язки громад.

Також діяв централізований підхід до формування місцевих бюджетів та збору місцевих податків. Відповідно до закону про місцеве самоврядування повноваження місцевих органів можна розділити на обслуговуючі та функціональні. Сектор функціональних повноважень залишав широку сферу впливу для центральних органів влади через міністерства чи регіональні органи влади. Повноваження громад у сфері обслуговування зводилися до організації діяльності закладів дошкільної освіти, будівництва, обслуговування місцевих автошляхів, визначення місць автостоянок, прибирання та освітлення вулиць, водопостачання, каналізації, утилізації твердих відходів, обслуговування кладовищ; виконання соціальної та культурної діяльності включаючи підтримку діяльності відповідних об'єктів (архіви, бібліотеки, музеї, освітні та дитячі заклади) місцевого значення; видача будівельних ліцензій [1, с.30 - 35].

Україна. Сучасний адміністративно-територіальний поділ України успадкований від радянської системи управління i, відповідно, є багаторівневим та складним. Найвищим рівнем управління в Україні $є$ загальнодержавний. На другому рівні територіального управління територія країни поділяється на 24 області, одну автономну республіку та два міста республіканського значення. Третім рівнем поділу в Україні є райони (всього 490) та міста обласного підпорядкування (187). Їм, в свою чергу, підпорядковуються:

- 271 міська рада, що формуються навколо міст районного значення;

- 781 селищна рада, що формуються навколо селищ міського типу;

- 9665 сільських рад, що формуються із одного чи декількох сіл;

- райони у містах із поділом на райони - 25 міст, на які разом припадає 111 районів.

Всього в Україні налічується 460 міст, 885 селищ міського типу, 10279 сільських рад та 27208 сільських населених пунктів [2]

У 2015 році в Україні стартувала адміністративно-територіальна реформа, результатом якої має бути утворення 1500 - 2000 спроможних територіальних громад замість понад 11 тисяч місцевих рад. Так, 5 лютого 2015 року Верховною Радою України був прийнятий Закон України «Про добровільне об'єднання територіальних громад» [3], відповідно до якого сусідні міські, селищні, сільські ради можуть об'єднатися в одну громаду, яка матиме один спільний орган місцевого самоврядування. Добровільне об'єднання територіальних громад здійснюється з дотриманням таких умов:
- у складі об'єднаної територіальної громади не може існувати іншої територіальної громади, яка має свій представницький орган місцевого самоврядування;

територія об'єднаної територіальної громади має бути нерозривною, межі об'єднаної територіальної громади визначаються по зовнішніх межах юрисдикції рад територіальних громад, що об'єдналися;

- об'єднана територіальна громада має бути розташована в межах території Автономної Республіки Крим, однієї області;

- при прийнятті рішень щодо добровільного об'єднання територіальних громад беруться до уваги історичні, природні, етнічні, культурні та інші чинники, що впливають на соціально-економічний розвиток об'єднаної територіальної громади;

- якість та доступність публічних послуг, що надаються в об'єднаній територіальній громаді, не можуть бути нижчими, ніж до об'єднання.

Адміністративним центром об'єднаної територіальної громади визначається населений пункт, який має розвинуту інфраструктуру i, як правило, розташований найближче до географічного центру території об'єднаної територіальної громади. Найменування об'єднаної територіальної громади, як правило, є похідним від найменування населеного пункту (села, селища, міста), визначеного ii адміністративним центром.

Добровільне об'єднання територіальних громад не призводить до зміни статусу населених пунктів як сільської чи міської місцевості.

8 квітня 2015 року Кабінет Міністрів України затвердив Методику формування спроможних територіальних громад [4]. У цій методиці вводиться термін «спроможна територіальна громада» - територіальні громади сіл (селищ, міст), які в результаті добровільного об'єднання здатні самостійно або через відповідні органи місцевого самоврядування забезпечити належний рівень надання послуг, зокрема у сфері освіти, культури, охорони здоров'я, соціального захисту, житловокомунального господарства, з урахуванням кадрових ресурсів, фінансового забезпечення та розвитку інфраструктури відповідної адміністративнотериторіальної одиниці.

Розглянемо варіант укрупнення територіальних громад на прикладі одного із адміністративних районів Рівненської області, а саме - Корецького.

Наразі на території Корецького району сформовано 25 сільських та одна міська громади. Всього у районі налічується 49 сіл, що означає, що у середньому до складу сільської ради входить по два села. Як видно на рисунку 1, жодна із сільських рад району за кількістю населення не наближається до обгрунтованого європейськими дослідженнями рівня, що становить 5 тис осіб. Натомість, дві сільські ради мають населення до 500 осіб, ще десять - від 500 до 1000 осіб, ще одинадцять - від 1 тис до 2 тис осіб і лише одна - понад 3 тис осіб.

На рис. 1 також видно, що населення по території сконцентровано нерівномірно - у північних заліс- 


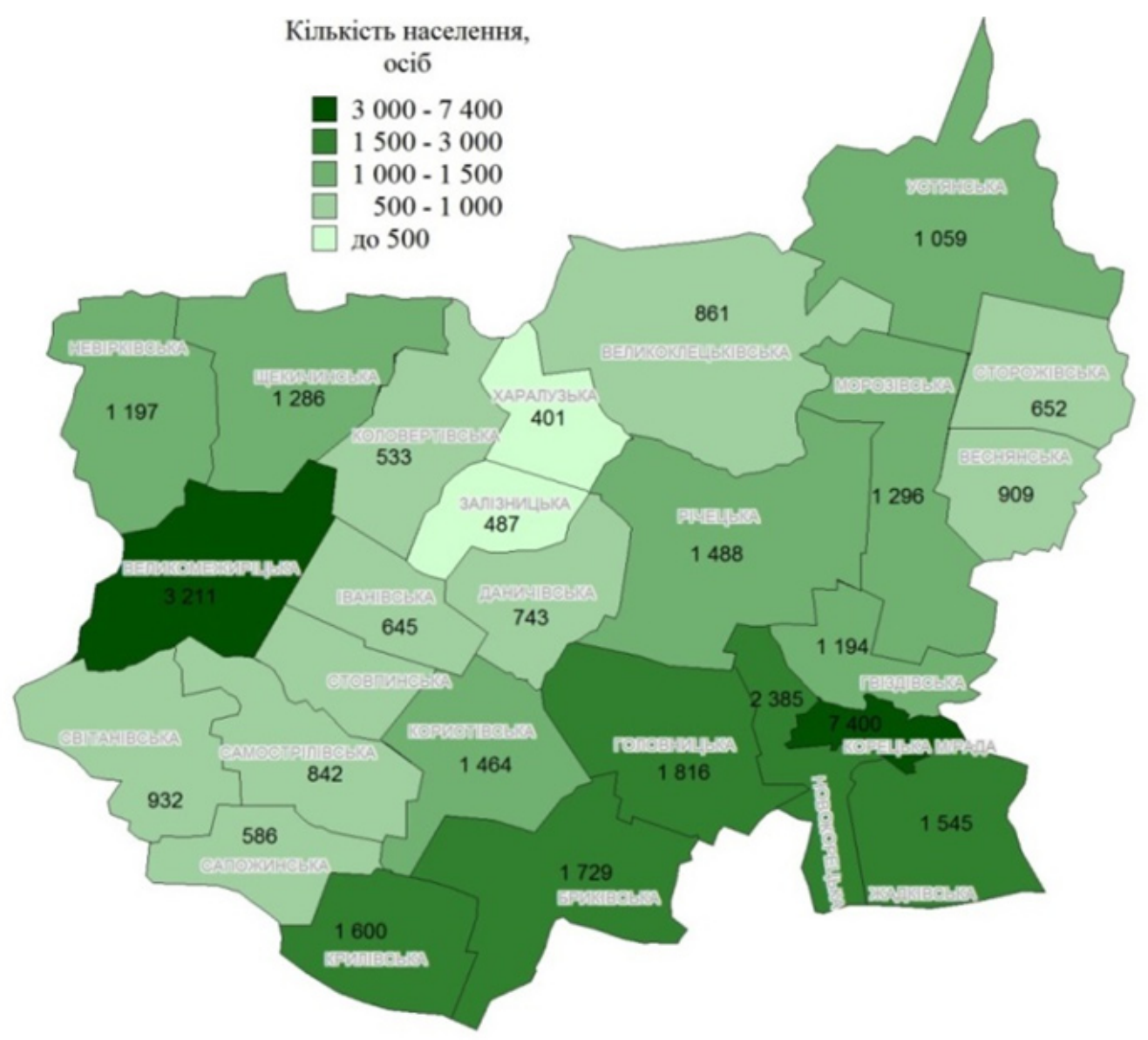

Рис. 1. Населення Корецького району Рівненської області у розрізі територіальних громад.

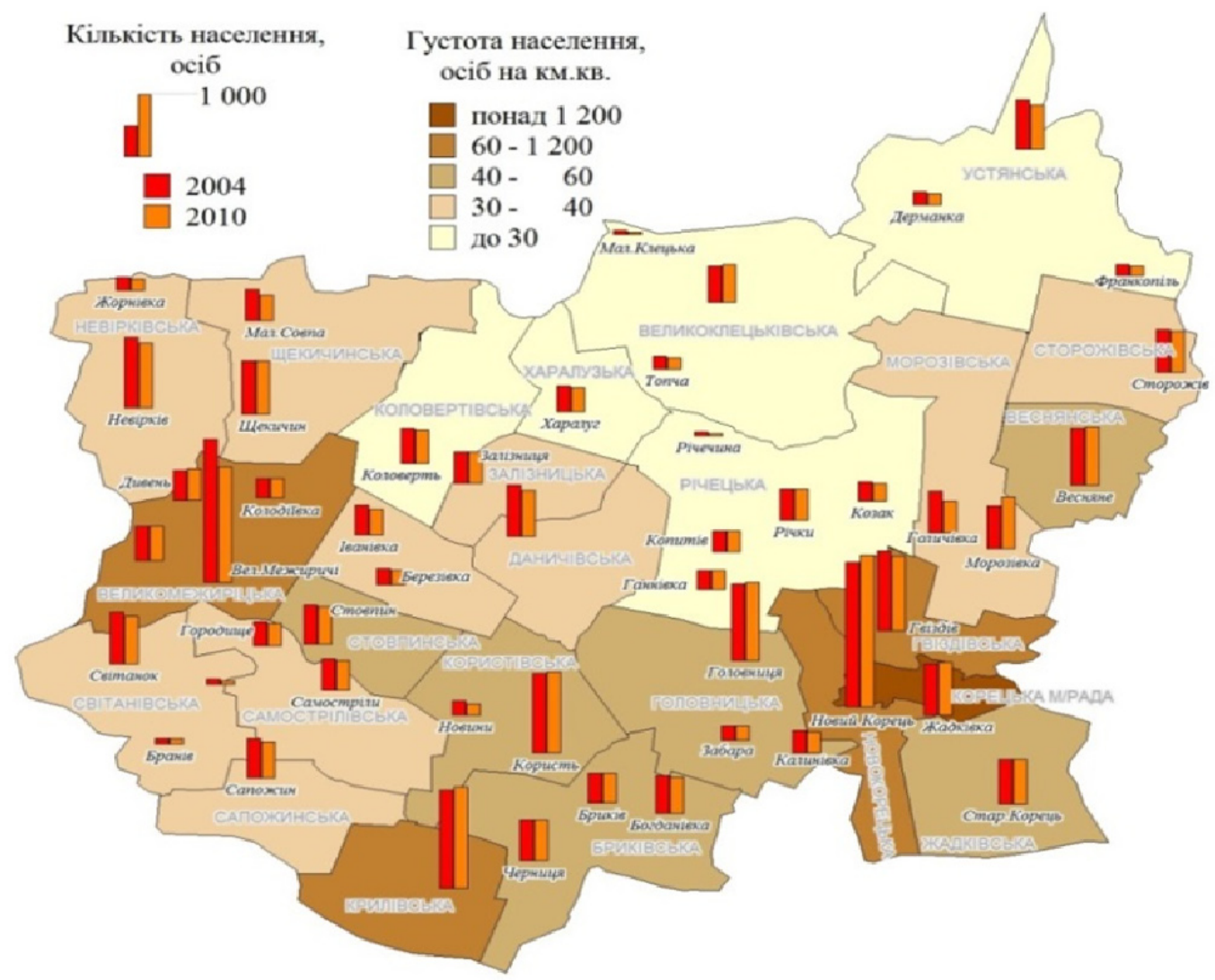

Рис. 2. Сільське населення Корецького району Рівненської області. 


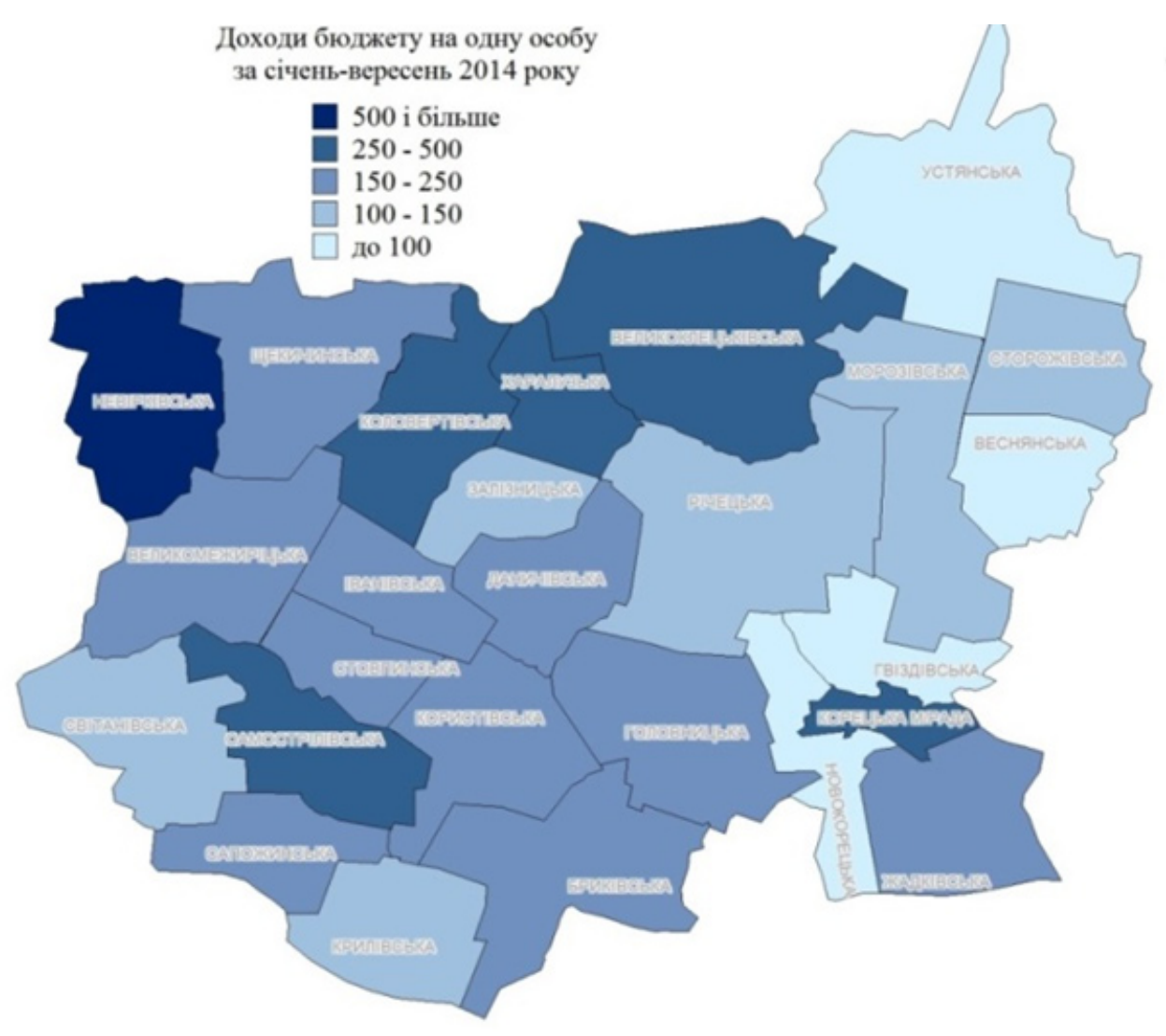

Рис. 3. Власні фінансові ресурси територіальних громад Корецького району Рівненської області.

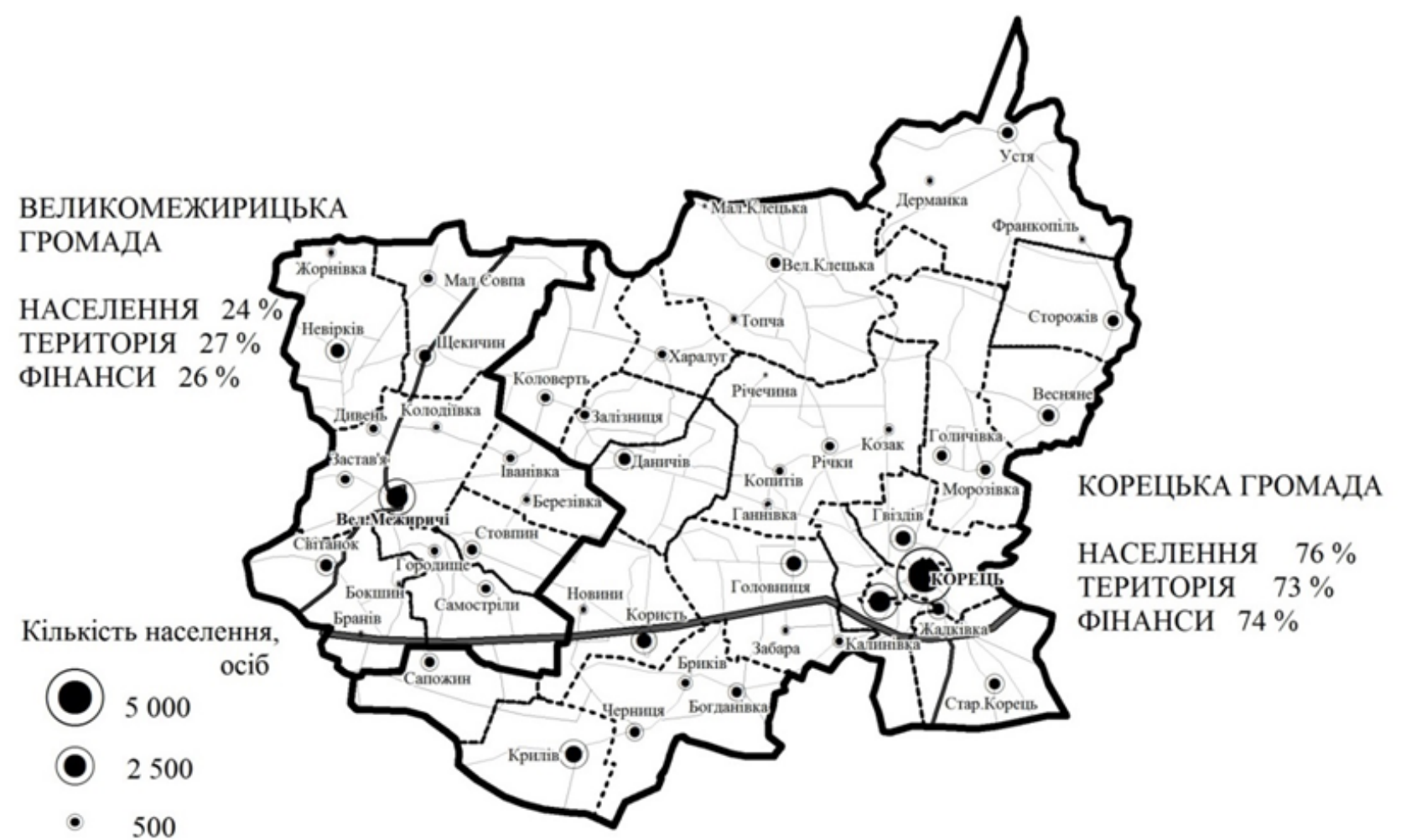

Рис. 4. Схема укрупнення громад на території Корецького району Рівненської області. 
нених територіях району густота населення $\epsilon$ найменшою, а найбільшою вона є навколо районного центру - міста Корця і навколо села Великі Межиричі, що раніше теж мав статус районного центру.

За площею території сільські ради району також значно відрізняються. Дані рис. 2 демонструють значні відмінності даного показника - від 14 км²

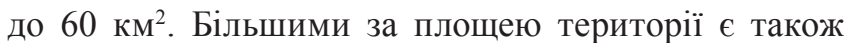
північні сільські ради району.

Проте найважливішим показником в умовах анонсованої децентралізації влади залишаються власні фінанси територіальних громад. Як видно на рис.3, вони коливаються від 70 до 610 грн на одну особу за 9 місяців 2014 року. Можна зробити висновок, що після передачі повноважень на місця більшість сільських рад району не зможуть забезпечити власні потреби для ефективного функціонування.

Для того, щоб запропонувати певний варіант об'єднання територіальних громад, окрім аналізу показників населення, території та фінансів, варто проаналізувати фактичне тяжіння населення до того чи іншого населеного пункту, розвиток транспортної інфраструктури, етнічний склад населення та інші.

Відповідно до схеми формування територіальних громад Рівненської області [5] запропоновано на території Корецького району сформувати дві територіальні громади - Корецьку та Великомежирицьку. Як видно на рис. 4, за пропорційним відношенням основних показників - кількість населення, територія, власні фінансові доходи - дані громади є майже рівнозначними. За такого поділу територіальні диспропорції соціальноекономічного розвитку території району мають знівелюватися.

Утворені громади мають об'єднатися навколо діючого районного центру - міста Корець, та села Великі Межиричі. Такий поділ є доцільним 3 точки зору тяжіння населення, особливостей будови транспортної системи та історичної зумовленості, адже с. Великі Межиричі мало статус селища міського типу i також було районним центром. Таким чином, населення новоутвореної Корецької громади становитиме близько 28,5 тис осіб та Великомежирицької - 8,5 тис осіб.

Висновки і перспективи подалыших розвідок. За підходом до територіально-адміністративного реформування Україна обрала варіант, близький до грузинського i, очевидно, що в процесі реформування доведеться зіткнутися із тими ж проблемами, що i в Грузії та інших країнах. Варто зауважити, що в Україні ця реформа збігається у часі із складними політичними, соціальними та фінансовими процесами, що тривають вже декілька років, що також створює значні ускладнення для швидкого та ефективного проведення адміністративнотериторіальної реформи. Відповідно, дана проблематика потребує подальшого вивчення, особливо фахівцями у галузі суспільної географії.

\section{References:}

1. Osoian I., Sorodoev I., Veveri’ă E., Prohni'chi V. Analytical Study on Optimal Administrative-Territorial Structure for Republic of Moldova. Chi'inău, 2010, 145 p.

2. Regioni Ukraïni ta ïh sklad [Regions of Ukraine and their composition]. Verkhovna Rada of Ukraine. Access mode: http://w1.cl.rada.gov.ua/pls/z7503/a002. (In Ukrainian).

3. The Law of Ukraine "On voluntary consolidation of territorial communities" dated February 5, 2015 N $157-$ VIII. Access mode: http://zakon5.rada.gov.ua/laws/show/157-19. (In Ukrainian).

4. Resolution of the Cabinet of Ministers of Ukraine "On Approval of the procedure used to create capable territorial communities” dated April 8, 2015 N 214. Access mode: http://zakon3.rada.gov.ua/laws/show/214-2015-ח. (In Ukrainian).

5. Shema formuvannâ teritorìal'nih gromad Rìvnens'koï oblastì [Scheme of formation of communities in Rivne Region]. Access mode: http://infolight.org.ua/sites/default/files/maps/ adminref/gromady_v2.htm\#10.00/50.6178/26.9768. (In Ukrainian). 